Wayne State University

DigitalCommons@WayneState

Social Work Faculty Publications

Social Work

$10-2-2013$

\title{
A Social Worker's Report from the United Nations Conference on Sustainable Development $($ Rio+20)
}

Richard J. Smith

Wayne State University, smithrichardj@wayne.edu

\section{Recommended Citation}

Richard John Smith. "A Social Worker's Report from the United Nations Conference on Sustainable Development (Rio + 20)" Social Work (2013) 58 (4): 369-372. doi: 10.1093/sw/swt032

Available at: http://digitalcommons.wayne.edu/soc_work_pubs/15 
NOTICE IN COMPLIANCE WITH PUBLISHER POLICY: This is a pre-copyedited, author-produced PDF of an article accepted for publication in Social Work following peer review. The definitive publisher-authenticated version, Richard John Smith. "A Social Worker's Report from the United Nations Conference on Sustainable Development (Rio + 20)" Social Work (2013) 58 (4): 369-372. doi: 10.1093/sw/swt032, is available online at: http://dx.doi.org/10.1093/sw/swt032. 


\title{
A Social Worker's Report from the United Nations Conference on Sustainable Development (Rio+20)
}

\author{
Richard J. Smith, MFA, MSW, PhD
}

In June 2012, heads of state convened to finalize a policy framework on sustainable development called "The Future We Want" at the United Nations Conference on Sustainable Development in Rio de Janeiro (Rio+20). To date, this is the largest United Nations gathering ever held with over 12,000 government officials and over 10,000 representatives of major groups (United Nations Department of Public Information, 2012). The two main themes of the conference were a) "a green economy in the context of sustainable development and poverty eradication and 2) the institutional framework for sustainable development"(United Nations, 2011a). The conference attendees presented ways to redefine economic growth as inclusive and how the green economy can provide decent jobs. This document will guide international sustainable development for the next ten years.

I joined this conference as part of the Ecocity Builders delegation, which convened the cities track for non-governmental organization major groups. Social workers and community organizers around the world would find this conference of interest because it emphasized the relationship between sustainable development and poverty eradication. The outcome document proposes to track progress using Sustainable Development Goals that will complement the Millennium Development Goals after 2015. The role of the United Nations Environmental Program will also be strengthened. Despite these achievements, the NGO major groups issued a statement rejecting the outcome document because it does not express the necessary commitment to change the direction of the world. 
Richard J. Smith

\section{Social Work and Social Development}

Social work has been involved with improving environmental conditions and eradicating poverty since the days of the Settlements. Globally, social development is the primary paradigm of poverty eradication. Social development as a process of planned change that combines community development with economic development (Midgley, 1995; Midgley \& Conley, 2010). Many nations have a Ministry of Social Development that organize micro-credit and other anti-poverty programs. Social development workers organize lending pools, cooperatives and nonformal education (Hall, 2004). Even some social work programs in the United States offer a social development curriculum that may asset building (Sherraden, 1990), for example. Recent social work texts have included chapters on sustainability and the environment (Estes, 2010; Gamble \& Weil, 2009; Mary, 2008; Wormer \& Besthorn, 2010) and scholars in the International Consortium for Social Development have argued that social work embrace the connections between social development and sustainability (Mohan, 2011) especially given the common theoretical interest in systems theory (Welch IV, 2012). Indeed, the US Council for Social Work Education made sustainability the theme for their 2010 conference in Portland, Oregon to explore ways of greening the profession

\section{The United Nations and Sustainable Development}

The path to Rio+20 builds on past environmental conferences including the 1972 Conference on the Human Environment in Stockholm. In 1987, the UN Brundtland Commission issued a report that recognized three pillars of sustainable development that include the environment, economy, and the social (Brundtland, 1987). The report defines sustainable development as meeting current needs in such a way that it does not compromise future generations. Often sustainability is framed as a cost that reduces economic growth and in turn increases unemployment. This report set the framework for the 1992 Earth Summit in Rio de Janeiro which resulted in treaties on climate change, desertification, and species protection. The follow actions of this conference were referred to as Agenda 21 and included common but differentiated responsibilities for each member state and embraced precautionary principle(United Nations, 


\section{A Social Worker's Report from the United Nations Conference}

$2011 b)$.

Meanwhile, on the anti-poverty front, the World Bank (1990) published a provocative report on global poverty that found one billion people living in abject poverty, on less than one US dollar a day. The 1995 World Summit on Social Development called for each country to measure and set goals regarding poverty. These became known as the Millennium Development Goals and the world pledged to cut global poverty in half as the first of many goals. The United Nations Department of Economic and Social Affairs (2004) convened the World Summit on Sustainable Development in Johannesburg in 2002 where the world reaffirmed its commitment to Stockholm, Agenda 21 and the Millennium Development Goals.

The United Nations General Assembly authorized Rio+20 and preparation for the conference took place in New York for more than a year (United Nations, 2011c). While diplomats representing heads of state actually draft the consensus document for approval, the United Nations has a consultative process with nine major groups representing business and industry; children and youth; farmers; indigenous people; local authorities; non-governmental organizations; scientific and technological community; women; and workers and trade unions. Each major group met prior to the conference in New York to make comments on the zero draft for consideration in the final document (United Nations, 2011d).

Meanwhile, the Government of Brazil organized the Rio Dialogues: a combination of social media conversations inviting broad participation from world citizens that culminated in a four day event prior to the main summit (Government of Brazil \& United Nations, 2012). Brazil invited representatives from major groups and ordinary citizens to submit proposals via the Rio Dialogues website. An expert panel picked the top ten proposals for each of the following categories: sustainable energy for all, forests, water, food security and nutrition, oceans, sustainable development for fighting poverty, sustainable cities and innovation, the economics of sustainable development including sustainable patterns of production and consumption, unemployment decent work \& migrations; and sustainable development as an answer to the economic and financial crises. These proposals were voted on by the world via the internet and the results were tabulated by continent, gender, human development index, and age. Attendees of the conference were allowed to vote on a 
second priority from the top ten. Brazil convened an expert panel for each topic and they facilitated a conversation with the audience before drafting a third recommendation for each category. The recommendation were consolidated and published as an annex to the official consensus document. Citizen engagement with social media innovation allowed access to information prior to the conference and to submit recommendations for consideration. The Government of Brazil also played a key role in keeping the editing of the consensus document on task between the preparatory conference and the main summit. Finally, from June 20th - 22nd, the heads of state and environment ministers arrived to approve the document, give speeches and hear from the major groups.

\section{Conflict Over Emissions, Women and War}

As expected following the experience in the Copenhagen climate negotiations, the nations of the world did not agree on key issues. Even the conference theme regarding the "green economy" generated controversy. In my opinion, there were too many unhelpful debates about which leg of Bruntland's stool is most important. Voices representing social and environmental organizations felt that a theme called "green economy" represented an affirmation that the economy is the most important leg in the sustainable development school. The best presentations were those that showed how each pillar is part of an interdependent system. Conference participants did agree that the way governments measure progress using indicators of general economic activity like Gross Domestic Product are in conflict with sustainable development because they do not account for the depletion of resources needed in future generations.

In general, the main block dominating the conference was the G77, a coalition of developing countries. They wanted to emphasize "common, but differentiated responsibilities" for sustainable development. On a practical matter, the G77 objected to language requiring cutting emissions unless the document included language about increased overseas development assistance (ODA) or favorable terms for technology transfer. The US opposed promises for increased ODA and insisted that any technology transfer be made with "mutually agreeable terms." Population, women's rights and reproductive health also became a controversy. The 


\section{A Social Worker's Report from the United Nations Conference}

Vatican took out language about sexuality education for adolescents and reproductive rights, but due to pressure by Secretary of State Clinton was unsuccessful in a bid to remove language about access to family planning (LaFranchi, 2012).

While we did end up with a document, civil society participants felt that the conference failed to address the critical issues of climate change, planetary boundaries, reducing emissions, increasing human population, nuclear energy, and the devastating impact of armed conflict. This NGO major groups delegation told the heads of state that the consensus document did not represent the aspirations of the world and did not reflect the input of civil society. These omissions are of interest to social workers because we are the ones who staff women's health clinics, provide mental health services to veterans, and resettle refugees of war or natural disasters (Ife, 2010). Also, Estes (2010) warns that given the reality of planetary boundaries, without a true peace dividend, world sustainability is threatened.

\section{The Future We Want?}

Despite the disappointments, the United Nations (2012) did agreed to the "Future We Want" that will form the policy framework regarding sustainable development for the next 10 years. One key outcome is the launch of the sustainable development goals (SDGs), which will replace the millennium development goals (MDGs) after 2015. This will allow countries to compete on their level of sustainability. There was also some interesting language about the rights of indigenous people to participate in a non-market economy. The role of cities as a solution to sustainable development was acknowledged. Consistent with the recommendations of Estes (2010), the UN Environmental Program (UNEP) will be strengthened and given more of a central role in sustainable development. Non-Governmental Organizations (NGOs) and member states as well as individuals are invited to make voluntary commitments towards sustainable development and register them with the United Nations.

For example, as the convener of the cities track of NGO major groups, Ecocity Builders made a voluntary commitment to partner with Local Governments for Sustainability (ICLEI), to develop International Ecocity Framework and Standards (IEFS) as shown in Figure 1. As a social 


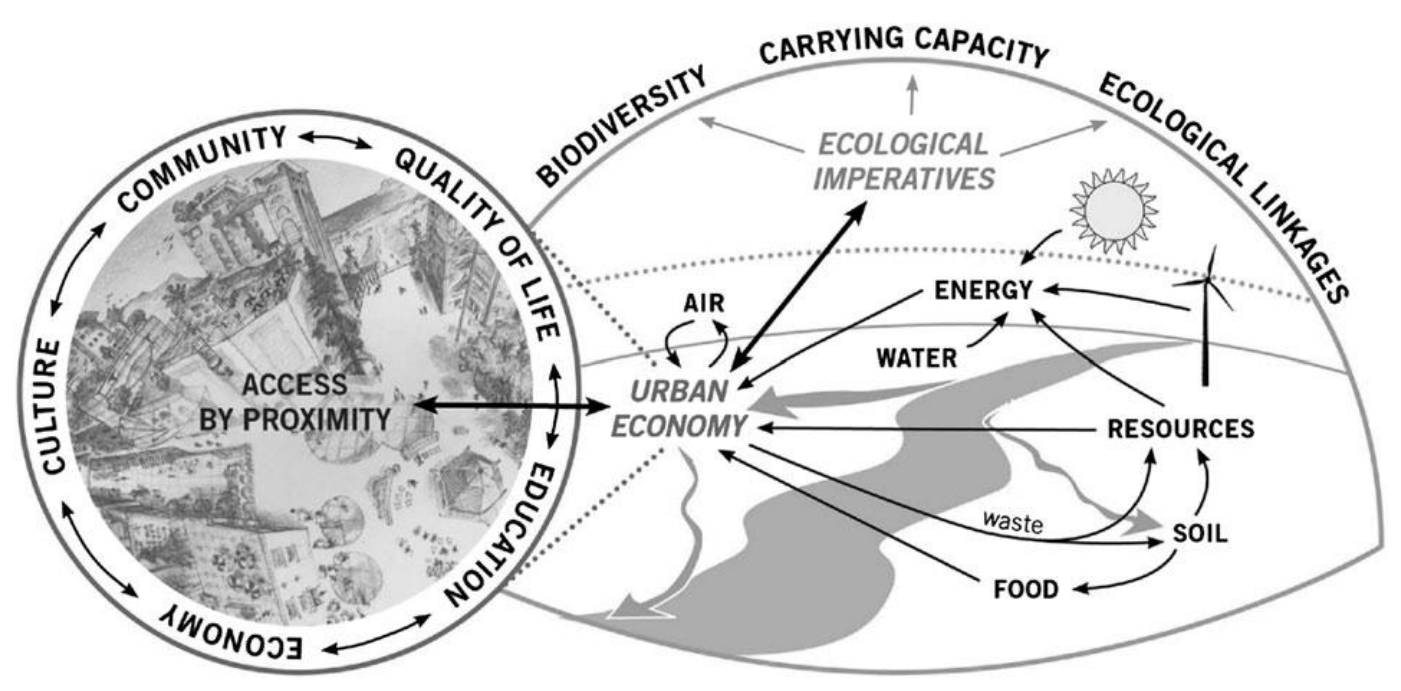

Figure 1: International Ecocity Framework and Standards Conditions

Source: Reprinted with permission of Ecocity Builders, Inc. (2011). Urban eco-system seen through the 15 dimensions of the International Ecocity Framework and Standards. Available at http://www.ecocitystandards.org/ecocity/systems-urban-ecology/

worker, I see this as an extension of the work done by communities across North America as part of the National Neighborhood Indicators Partnership (2012) and the Community Quality of Life Indicators (Sirgy, 2011) research series. Social workers have participated in both of these professional networks to identify indicators of well being that can be used to track the progress of local programs. While it would have been preferable to have global consensus to take bold action, we still have an opportunity to have a voice in the development of the SDGs. At the conference, Jeffery Sachs of Columbia University argued that the MDGs succeeded because they were not imposed by a treaty but a transparent contest of nations to achieve basic human need. In fact, three MDGs have already been met to cut global poverty, substandard housing, and lack of adequate water in half (United Nations News Service Section, 2012). Collective action and global partnerships can make a difference. Social work as a profession should partner the nations of the world to develop SDGs globally and participate in implementing them locally. 
A Social Worker's Report from the United Nations Conference

\section{References}

Brundtland, G. H. (1987). Our common future: Report of the world Commission on Environment and Development. New York, N.Y: United Nations.

Estes, R. J. (2010). Toward sustainable development: From theory to praxis. Transnational Social Work Practice (pp. 76-110).

Gamble, D. N., \& Weil, M. (2009). Community Practice Skills: Local to Global Perspectives. Columbia University Press.

Government of Brazil, \& United Nations. (2012). Final Recommendations. Presented at the Sustainable Development Dialogue Days, Rio de Janeiro, Brazil. Retrieved from http://www.uncsd2012.org/sddialoguedays.html

Hall, A. L. (2004). Social Policy for Development. London ; Thousand Oaks, Calif: SAGE.

Ife, J. (2010). The new international agendas: what role for social work? Journal of Social Intervention Research, 1, 80-102.

LaFranchi, H. (2012, June 22). Rio+20 earth summit: Why Hillary Clinton won applause for statement on women. Christian Science Monitor. Retrieved from http://www.csmonitor.com/USA/ForeignPolicy/2012/0622/Rio-20-earth-summit-Why-Hillary-Clinton-wonapplause-for-statement-on-women

Mary, N. L. (2008). Social Work in a Sustainable World. Lyceum Books, Inc.

Midgley, J. (1995). Social development : the developmental perspective in social welfare. London: Sage Publications.

Midgley, J., \& Conley, A. (2010). Social work and social development: theories and skills for developmental social work. Oxford University Press. 
Mohan, B. (2011). Rights, Responsibility, and Renaissance: The Three Rs of Sustainable Development. Social Development Issues, 33(3), 67-79.

National Neighborhood Indicators Partnership. (2012). National

Neighborhood Indicators Partnership. Retrieved March 26, 2010, from http://www.neighborhoodindicators.org/

Sherraden, M. (1990). Assets and the poor: A new American welfare policy. Armonk, NY; London, England: M. E. Sharpe, Inc.

Sirgy, M. J. (Ed.). (2011). Community Quality-of-Life Indicators. New York: Springer. Retrieved from http://www.springer.com/series/8363

United Nations. (2011a). Objectives and themes. Rio+20 - United Nations Conference on Sustainable Development. Retrieved June 26, 2012, from http://www.uncsd2012.org/objectiveandthemes.html

United Nations. (2011b). The History of Sustainable Development in the United Nations. Rio+20 - United Nations Conference on Sustainable Development. Retrieved July 9, 2012, from http://www.uncsd2012.org/history.html

United Nations. (2011c). Process. Rio+20 - United Nations Conference on Sustainable Development. Retrieved July 9, 2012, from http://www.uncsd2012.org/rio20process.html

United Nations. (2011d). Major groups. Rio+20 - United Nations Conference on Sustainable Development. Retrieved July 9, 2012, from http://www.uncsd2012.org/majorgroups.html

United Nations. (2012, June 22). The Future We Want. Retrieved from http://www.uncsd2012.org/thefuturewewant.html

United Nations Department of Economic and Social Affairs. (2004, December 14). WSSD Political Declaration. Division for Sustainable Development-. Retrieved July 4, 2012, from 
A Social Worker's Report from the United Nations Conference

http://www.un.org/esa/sustdev/documents/WSSD_POI_PD/Engli sh/POI_PD.htm

United Nations Department of Public Information. (2012, June 23). Rio+20 in Numbers. Retrieved July 4, 2012, from

http://www.uncsd2012.org/index.php?page=view\&nr=1304\&type $=230 \&$ menu $=38$

United Nations News Service Section. (2012, July 2). Global partnership key to achieving Millennium Development Goals by 2015 - UN report. UN News Service Section. Retrieved July 4, 2012, from http://www.un.org/apps/news/story.asp?NewsID $=42372 \& C r=m$ $\operatorname{dg} \& \mathrm{Cr} 1=$

Welch IV, J. (2012). Sustainability and Social Development: An Integrative Examination. Social Development Issues, 34(1), 56-76.

World Bank. (1990). World Development Report 1990: Poverty.

Wormer, K. van, \& Besthorn, F. H. (2010). Human Behavior and the Social Environment, Macro Level: Groups, Communities, and Organizations (2nd ed.). Oxford University Press, USA. 